International Journal of Zoological Investigations

Contents available at Journals Home Page: www.ijzi.net

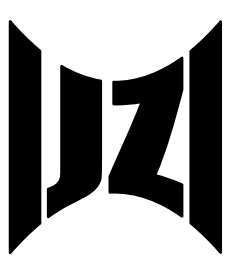

ISSN: 2454-3055

\title{
Diversity and Distribution of Snakes in Adjoining Areas of Panvel, Navi Mumbai, West Coast of India
}

\author{
Pawar Prabhakar R. ${ }^{*}$, Rokade Anil G., Supnekar Santosh P., Meshram Leena N., Pawar Namdeo B. \\ and Gavhane Usha V. ${ }^{2}$
}

${ }^{1}$ Mahatma Phule Arts, Science and Commerce College, Panvel, Raigad, Navi Mumbai - 410206, India
2Shri Shivaji Mahavidyalaya, Barsi, Solapur, India

*Corresponding Author

Received: $10^{\text {th }}$ June, 2020

Accepted: $8^{\text {th }}$ July, 2020

Published online: $12^{\text {th }}$ July, 2020

https://doi.org/10.33745/ijzi.2020.v06i02.007

\begin{abstract}
In this study, impact of over-exploitation of natural resources on diversity and distribution of snakes in adjoining areas of Panvel, Navi Mumbai was assessed. The present work was carried out for one year (from June 2019 to May 2020). Study sites were visited during dawn and dusk hours, one day in each month. Also, data on snakes was collected from local snake friend NGOs and reports of accidental road kills. This study observed 25 species of snakes representing 10 families and 23 genera out of which 10 species belong to family Colubridae, 3 species each to Elapidae and Viperidae, 2 species each to Erycidae and Natricidae and 1 species each to Homalopsidae, Lamprophiidae, Pythonidae, Sibynophiidae and Typhlopidae. During present study, 19 species of non-venomous snakes and 6 species of venomous snakes were observed. The study shows that, ecological conditions in area adjoining to Panvel, Navi Mumbai supports moderate snake density. It can be concluded that over-exploitation of natural resources in Panvel region due to ongoing construction of Navi Mumbai International Airport (NMIA) are the key factors affecting the diversity and distribution of snakes. Also, mortality of snakes in residential complexes is due to lack of awareness regarding ecological role of snakes and fear of snake bite. It is recommended to create awareness among general public about role of snakes in ecological food chain and also sustainable utilization of natural resources. Since no earlier reports are available, data presented here can be taken as a baseline data in knowing the status of snakes from adjoining area of Panvel, Navi Mumbai.
\end{abstract}

Keywords: Diversity, Natural resources, Navi Mumbai International Airport, Panvel, Reptilia, Snakes

Citation: Pawar Prabhakar R., Rokade Anil G., Supnekar Santosh P., Meshram Leena N., Pawar Namdeo B. and Gavhane Usha V.: Diversity and distribution of snakes in adjoining areas of Panvel, Navi Mumbai, West Coast of India. Intern. J. Zool. Invest. 6 (2): 289-300, 2020. https://doi.org/10.33745/ijzi.2020.v06i02.007 


\section{Introduction}

Interest in conservation of biodiversity increased due to population declines and extinctions throughout the world by reasons like habitat loss and degradation, unsustainable use, invasive species, environmental pollution, disease and global climate change (Masood, 2012). Asia was considered among most diversity-rich continents; however, increase in human population has adversely affected the diversity due to agriculture intensification, urbanization, industrialization, and pollution (Gibbons et al., 2000; Altaf et al., 2018).

Species are the backbone of biology (Uetz, 2010). Among vertebrates, reptiles are still poorly known and are highly threatened. Decline in population of reptiles is a major concern and causes of catastrophic decline are habitat loss, environmental pollution, lethal diseases, unsustainable use of natural resources and global climate change (Rodrigues et al., 2010; Koirala et al., 2016; Vignoli et al., 2017; Luiselli et al., 2020).

With more than 3000 species known so far, snakes are a successful group of predatory vertebrates that occupy tropical and temperate areas, from deserts and mountain summits to oceans (Pauwels et al., 2008). Snakes are important groups of reptiles to conquer the terrestrial ecosystem and play an important role in the ecosystem as links in food webs, predators and prey, bio-monitors in controlling insect pests and ecological indicators owing to their high degree of sensitivity to even a slight change in the environment (Koirala et al., 2016; Bohm et al., 2017).

India harbours 518 species of reptiles which include 279 species of snakes belonging to 28 families. All over the world, near about 3783 snake species are found, out of which 279 species of snakes are found only in the India (Janani et al., 2016). They constitute approximately 10 per cent of the total snake species found in the world and $80 \%$ of them are non-poisonous (Kale et al., 2019). The venomous snakes include only about 58 species and there are only 4 species of snakes that are dangerous to man, namely, Cobra, Krait, Russell's viper and Saw-scaled viper (Jadhav et al., 2018).

Coastal environment of Navi Mumbai (Panvel, Uran, Vashi) has been under considerable stress since the ongoing construction of Navi-Mumbai International Airport (NMIA) by the City and Industrial Development Corporation (CIDCO). Construction of NMIA has resulted into deforestation, encroachment, reclamation and urbanization in the study area. It has affected the livelihood of local fishermen and coastal community along with ecology of fauna from Panvel, Navi Mumbai (Pawar, 2013, Pawar et al., $2019 \mathrm{a}, \mathrm{b})$.

Details on diversity and distribution of snakes in India have been studied by Ganesh et al. (2013), Fellows (2014), Pradhan et al. (2014), Raut et al. (2014), Yadav et al. (2014), Bansode et al. (2016), Bawaskar and Bawaskar (2016), Janani et al. (2016), Manhas et al. (2016), Mukadam and Kadam (2016), Sirsat et al. (2016), Tambre and Chavan (2016), Joshi et al. (2017), Baishya and Das (2018), Bansode and More (2018), Jadhav et al. (2018), Lalremsanga et al. (2018), Sulabh and Shivahre (2018) and Kale et al. (2019).

Although many studies have been undertaken to evaluate the species diversity 
and distribution of snakes in India, barring the work of Walmiki et al (2012), no scientific studies have been carried out on the species composition and distribution of snakes of Mumbai and Navi Mumbai; hence, the present study is undertaken. In the present study, an attempt has been made to document the diversity and distribution of snakes in Panvel, Navi Mumbai and its adjoining area to assess the impact of anthropogenic activities.

\section{Materials and Methods}

Study Area:

Navi Mumbai is basically a satellite township on the west shore of Maharashtra. It was made in 1971 to be another urban township of Mumbai by Government of Maharashtra. As per Census India 2011, it had a population of $1,119,477$. Panvel is located in Raigad district of Maharashtra in Konkan region and is a node of Navi Mumbai city. Geographically, Panvel is near Panvel creek which opens up in Thane creek. Kalundre river flows across the city in the south-west region and opens up into Panvel creek. Panvel with a population of 180,464 (Census India 2011) is a highly populated city due to its closeness to Mumbai. It is located in the Mumbai Metropolitan Region. Panvel is situated on the banks of Panvel Creek. It is also surrounded by mountains on 2 sides (Fig. 1).

\section{Study Location:}

The present ecological study on diversity and distribution of snakes was carried out for the period of one year, from June 2019 to May 2020. Area adjoining to Panvel was visited during dawn and dusk hours, one day in each month and $4 \mathrm{~h}$ were spent at each site at both times. Also, data of snakes was collected from local snake friend NGOs as well as from the reports of accidental road kills. All snakes were photographed using Cannon $1100 \mathrm{D}$ Zoom camera. For correct identification of snakes. field guides and books of Daniel (2002), Whitaker (2006) and Petty (2019) were followed.

\section{Results and Discussion}

Varied diversity of snakes with 25 species representing 10 families and 23 genera were observed. Number of species of snakes distributed in each family reveals that 10 species belongs to family Colubridae, 3 species each to Elapidae and Viperidae, 2 species each to Erycidae and Natricidae and 1 species each to Homalopsidae, Lamprophiidae, Pythonidae, Sibynophiidae and Typhlopidae. During present study, 19 species of nonvenomous snakes and 6 species of venomous snakes were recorded (Figs. 2, 3; Tables 1, 2,).

Masood (2012) reported that though the venomous snakes may be harmful to human life in some cases, they are also useful to human in many aspects of life and are required to be conserved by maintaining suitable natural habitat. Koirala et al. (2016) noted that protection of forest habitats are significantly important for conservation of herpetofauna diversity. According to Bohm et al. (2017), factors like altitude, habitat breadth and body size of snakes are also to be considered for effective conservation of reptiles.

Luiselli et al. (2020) observed a positive correlation between habitat and abundance of venomous snakes and factors like human population density, dominant agricultural techniques and land use severely affects the relative abundance of venomous snake species. Vignoli et al. (2017) recorded 


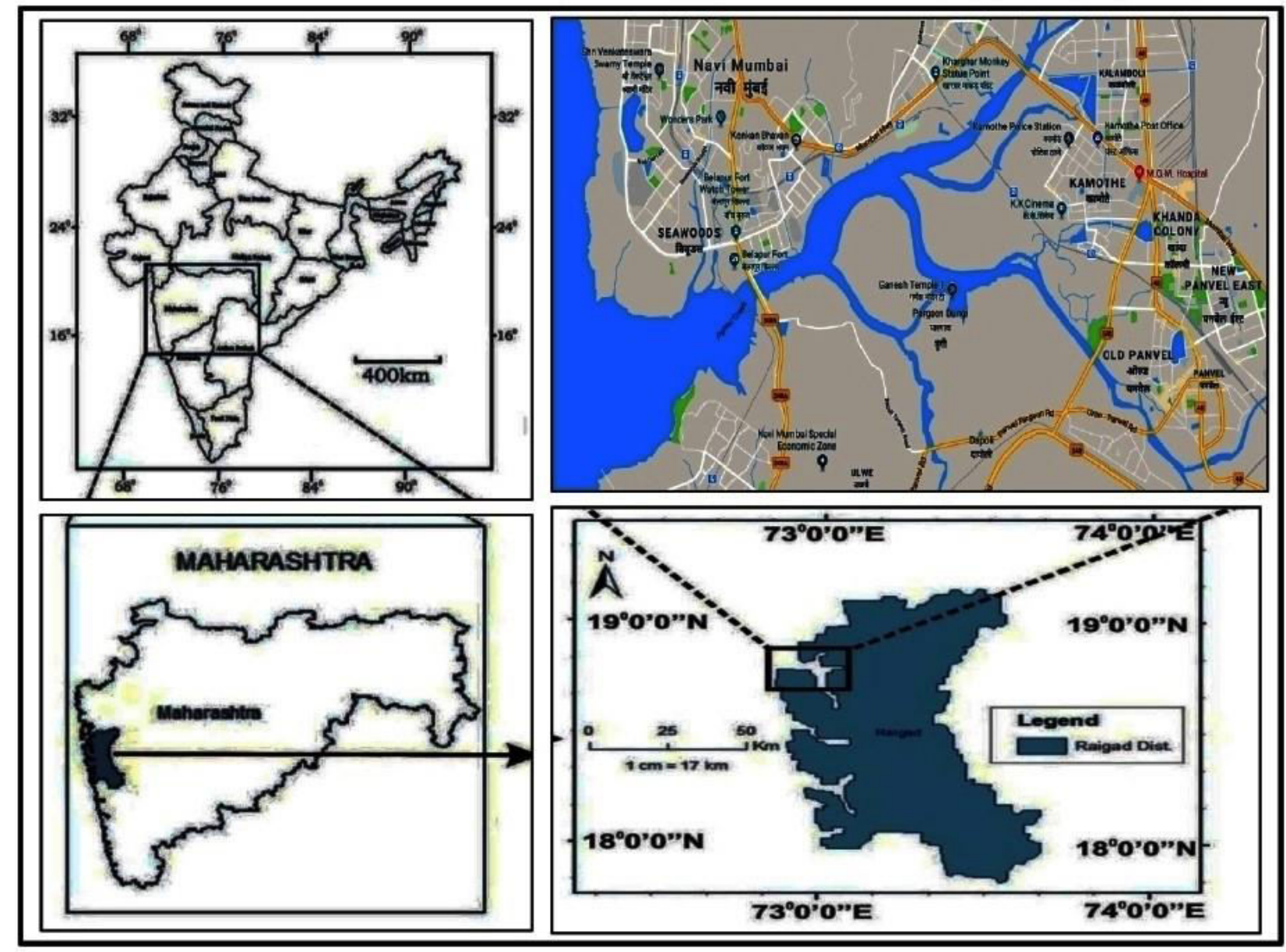

Fig. 1. Location map of study area representing Panvel creek.

distribution and diversity of reptiles in a species-rich protected area of central Italy and stated that natural land use supports the whole reptile community where as urban and agricultural environments hosted about half of the species.

Pawar et al. (2019 a, b) correlated the depletion of coastal marine diversity from Panvel creek to the loss of habitat due to deforestation, overexploitation of natural resources for ongoing construction of NaviMumbai International Airport (NMIA), habitat fragmentation due to construction and widening of roads and rampant urbanization and industrialization of the area adjoining Panvel.

Ongoing construction of NMIA covers an area of 1,160 hectares (4.5 Sq miles) in the vicinity of Panvel creek. The airport project has relocated 2,786 households located across 10 villages. Villages like Chinchpada, Kopar, Kolhi, Ulve, Upper Owale, Waghivalipada, Vaghivali, Ganeshpuri, Targhar and Kombadbhunje are relocated in the nearby area of creek. The airport area has to be filled with an average of 14 feet. For filling the airport area, nearby mountain resources were excavated at an alarming rate, without 


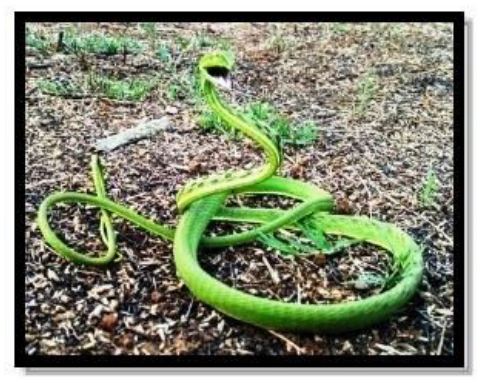

Ahaetulla nasuta

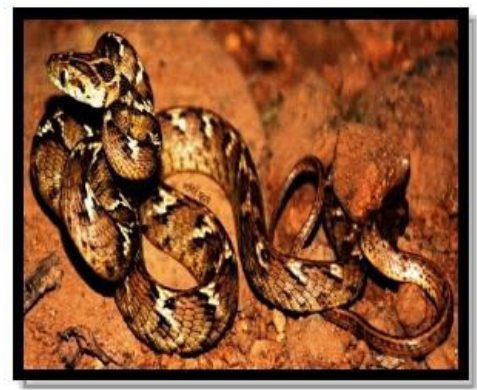

Boiga trigonata

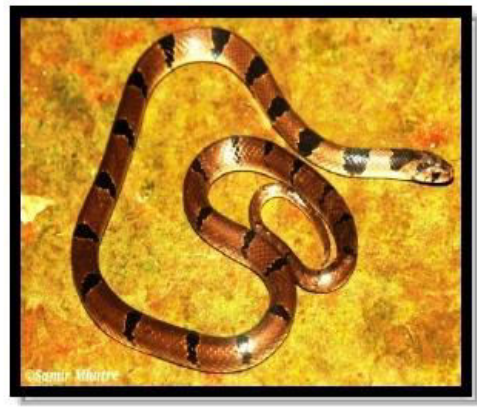

Oligodon arnensis

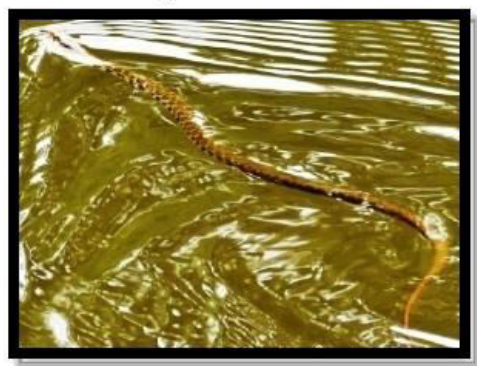

Xenochrophis piscator

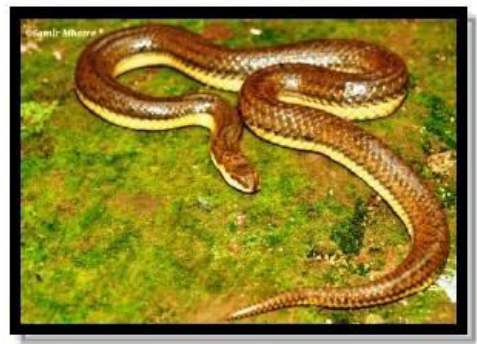

Gerarda prevostiana

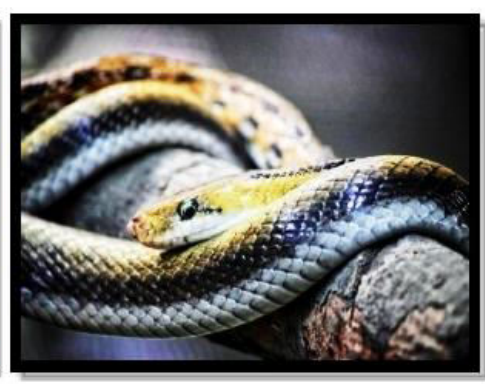

Archelaphe bella

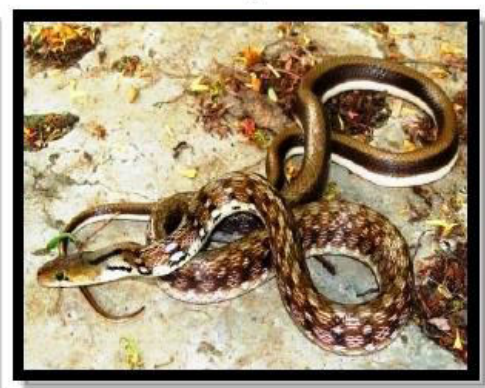

Coelognathus helenus

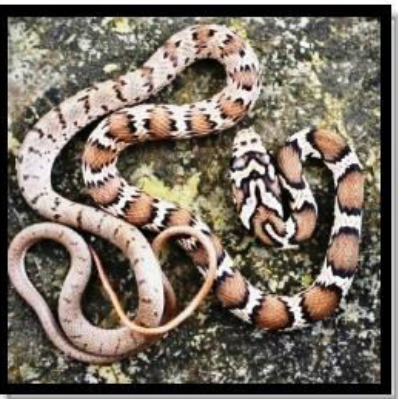

Platyceps gracilis

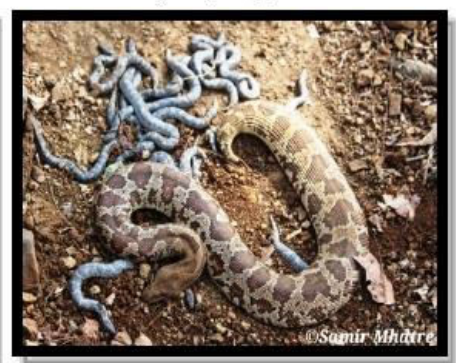

Eryx conicus

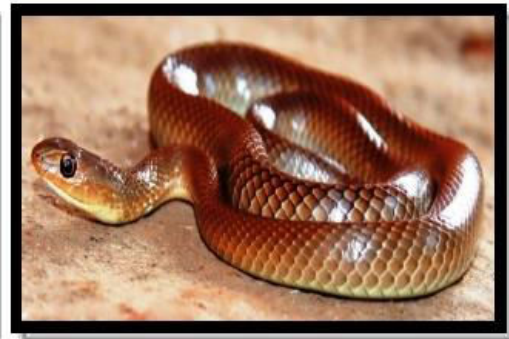

Psammophis longifrons

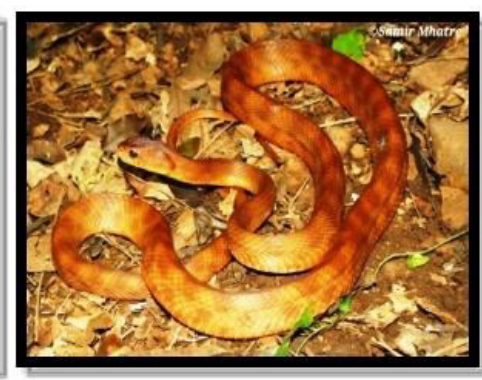

Boiga forsteni

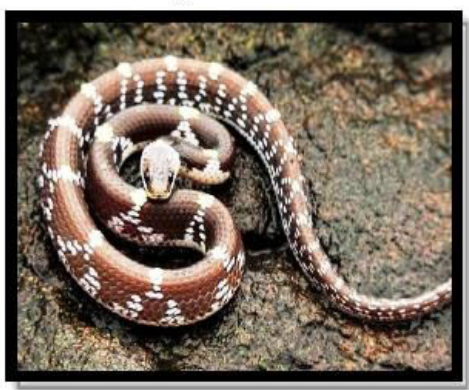

Lycodon aulicus

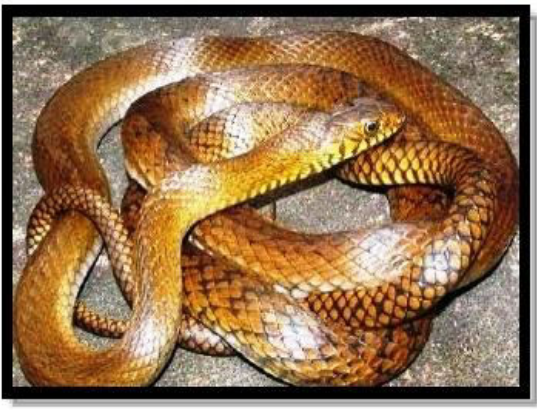

Ptyas mucosa

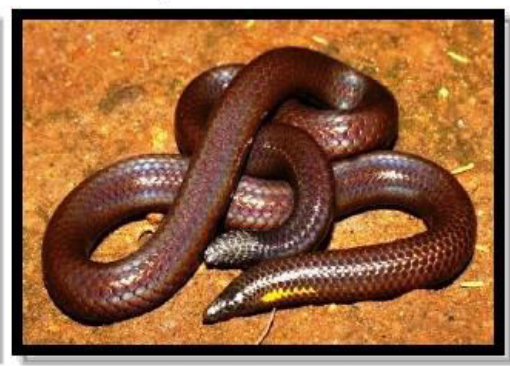

Eryx johnii

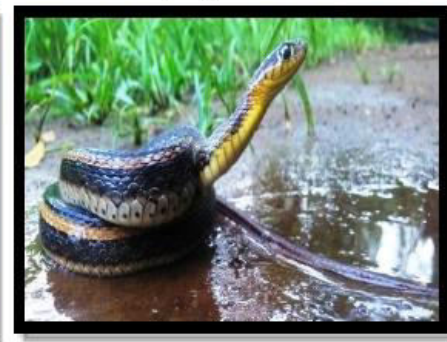

Amphiesma stolatum

Fig. 2: Snakes recorded in \& around Panvel, Navi Mumbai during June 2019 to May 2020 


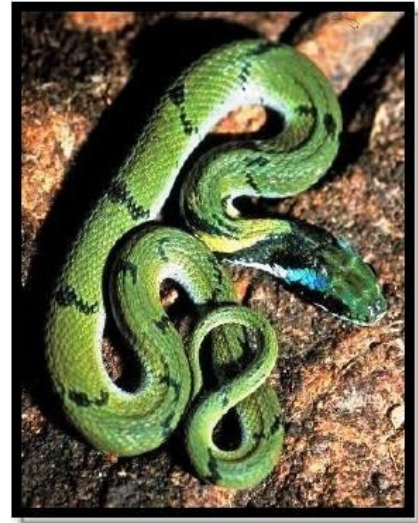

Macropisthodon plumbicolor

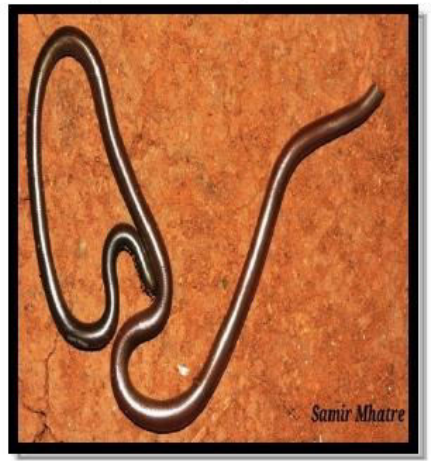

Indotyphlops braminus

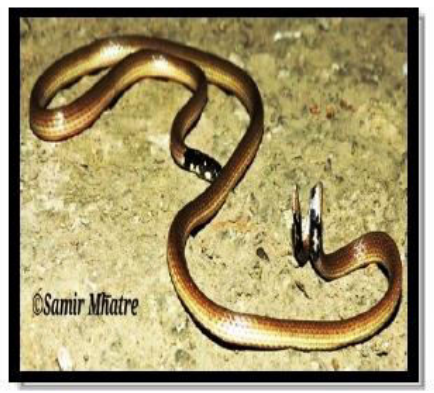

Calliophis melanurus

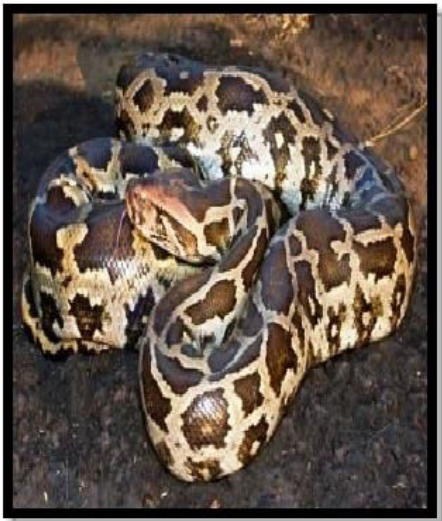

Python molurus

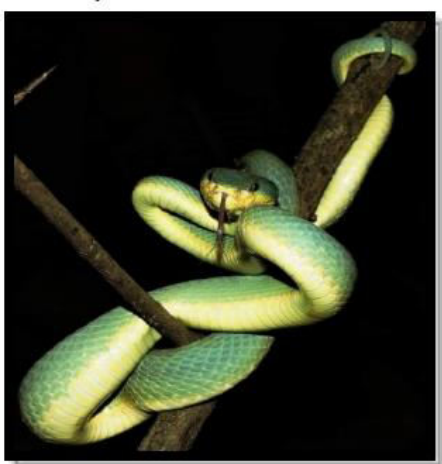

Trimeresurus gramineus

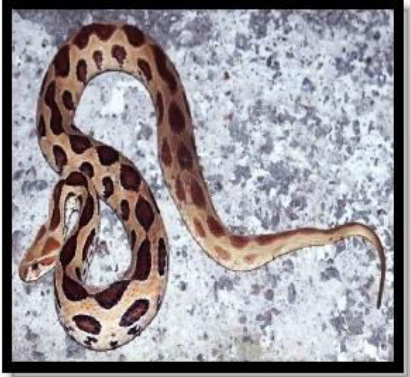

Daboia russelii

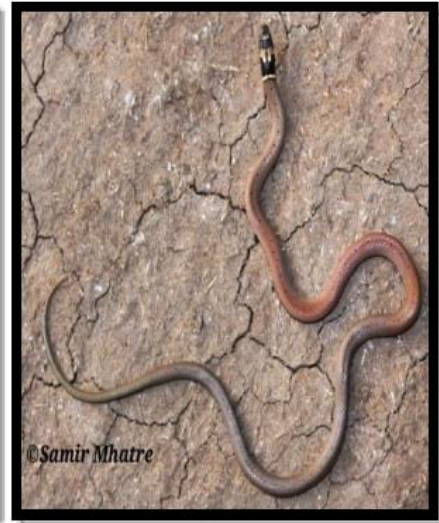

Sibynophis subpunctatus

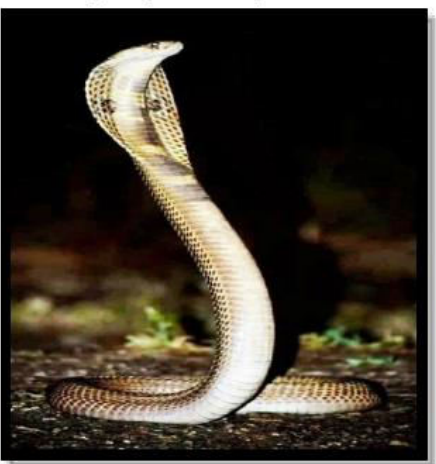

Naja naja

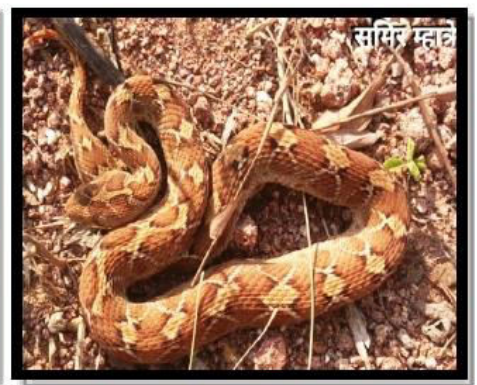

Echis carinatus

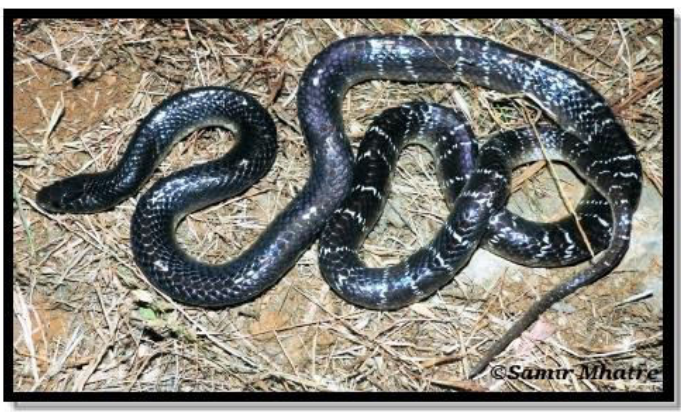

Bungarus caeruleus

Fig. 3: Snakes recorded in \& around Panvel, Navi Mumbai during June 2019 to May 2020 


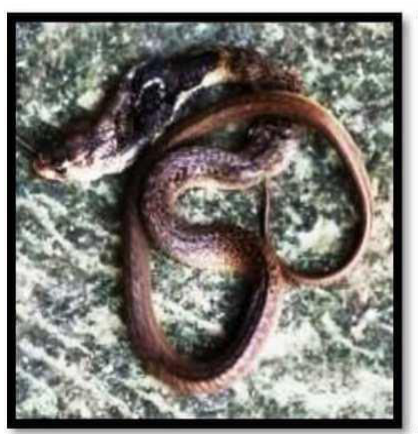

Spectacled Cobra

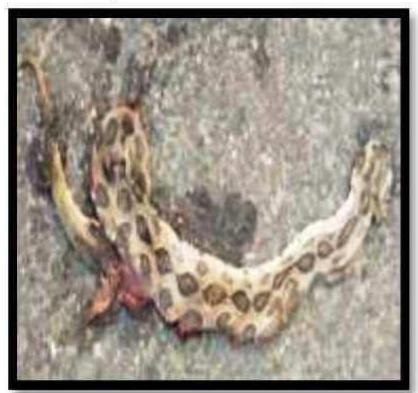

Russell's Viper

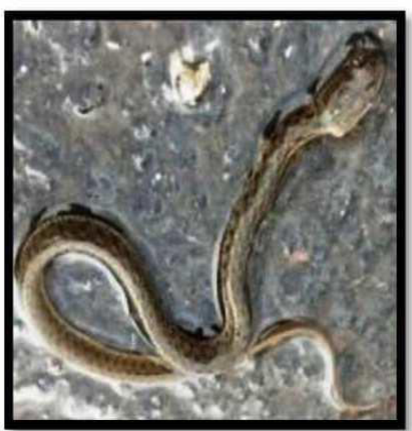

Checkered Keelback

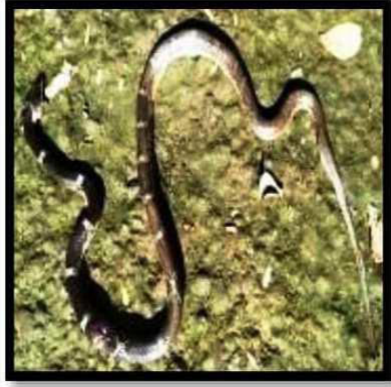

Common Wolf Snake

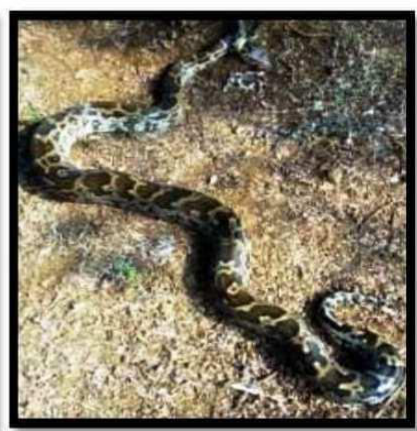

Indian Rock Python

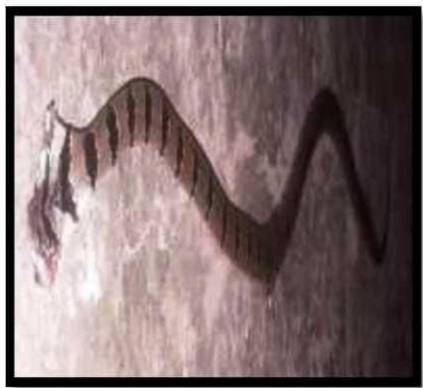

Banded Kukari

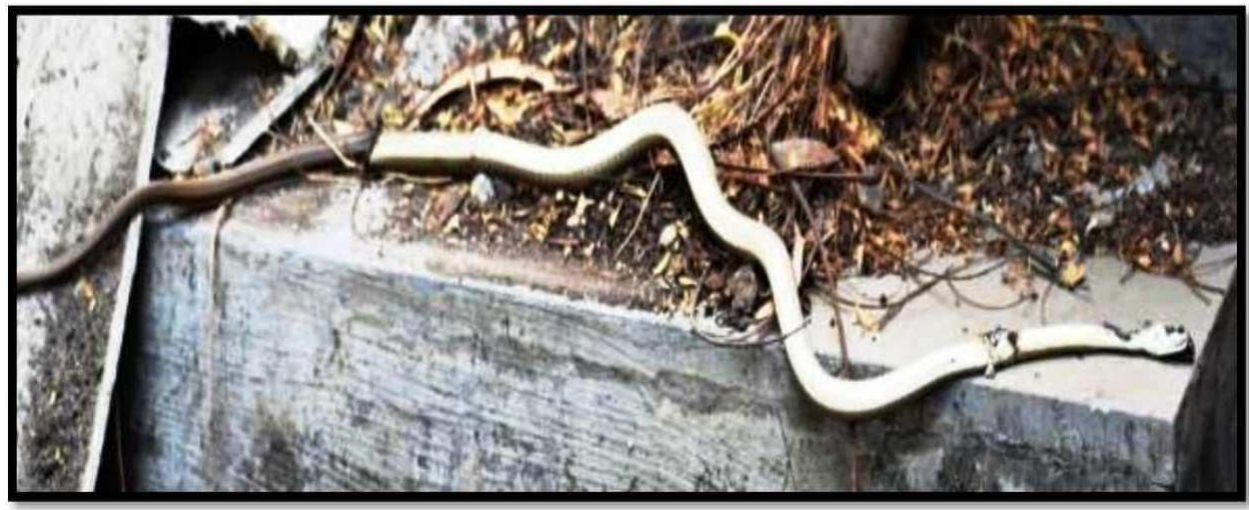

Rat Snake

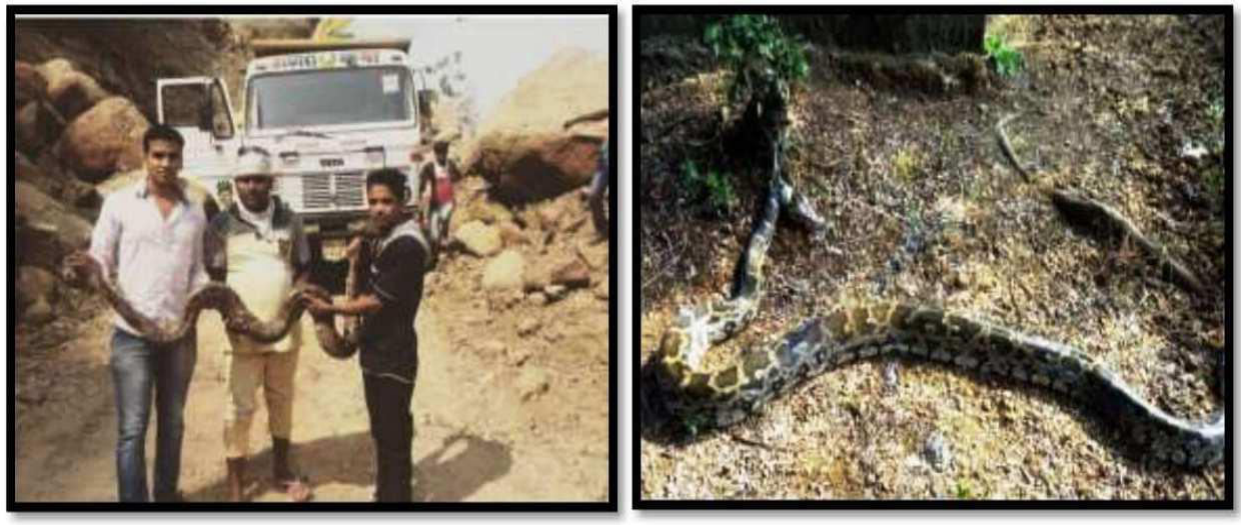

Indian Rock Python

Fig. 4: Anthropogenic impact \& accidental road kills of snakes from Panvel, Navi Mumbai 
Table 1: Preliminary checklist of snakes (Order: Squamata) recorded in and around Panvel

\begin{tabular}{|c|c|c|c|}
\hline No. & Family & Scientific Name & Common name \\
\hline & \multicolumn{3}{|c|}{ Non-Venomous Snakes (NV) } \\
\hline 1 & Colubridae & Ahaetulla nasuta (Bonnaterre, 1790) & $\begin{array}{l}\text { Long-nosed Tree Snake, } \\
\text { Green Vine Snake }\end{array}$ \\
\hline 2 & & Archelaphe bella (Stanley, 1917) & Bella's Trinket Snake \\
\hline 3 & & $\begin{array}{c}\text { Boiga forsteni (Dumeril, Bibron and Duméril, } \\
\text { 1854) }\end{array}$ & Forsten's cat snake \\
\hline 4 & & Boiga trigonata (Schneider, 1802) & $\begin{array}{l}\text { Common Cat Snake, } \\
\text { Indian Gamma Snake }\end{array}$ \\
\hline 5 & & $\begin{array}{l}\text { Coelognathus helenus } \\
\text { (Daudin, 1803) }\end{array}$ & Common Trinket Snake \\
\hline 6 & & Lycodon aulicus (Linnaeus, 1758) & Common Wolf Snake \\
\hline 7 & & Oligodon arnensis (Shaw, 1802) & Banded Kukri Snake \\
\hline 8 & & Platyceps gracilis (Gunther, 1862) & $\begin{array}{l}\text { Slender Racer Snake, } \\
\text { Gunther's Racer }\end{array}$ \\
\hline 9 & & Ptyas mucosa (Linnaeus, 1758) & Rat Snake \\
\hline 10 & & $\begin{array}{l}\text { Xenochrophis piscator } \\
\text { (Schneider, 1799) }\end{array}$ & $\begin{array}{l}\text { Checkered Keelback, } \\
\text { Asiatic Water Snake }\end{array}$ \\
\hline 11 & Erycidae & Eryx conicus (Schneider, 1801) & Common Sand Boa \\
\hline 12 & & Eryx johnii (Russell, 1801) & $\begin{array}{c}\text { Red Sand Boa, } \\
\text { Indian Red Sand Boa }\end{array}$ \\
\hline 13 & Homalopsidae & $\begin{array}{c}\text { Gerarda prevostiana } \\
\text { (Eydoux and Gervais, 1837) }\end{array}$ & $\begin{array}{l}\text { Glossy Marsh Water Snake, } \\
\text { Gerard's Water Snake, } \\
\text { Gerard's Mud Snake }\end{array}$ \\
\hline 14 & Lamprophiidae & $\begin{array}{c}\text { Psammophis longifrons } \\
\text { (Boulenger, 1890) }\end{array}$ & $\begin{array}{l}\text { Stout Sand Snake, } \\
\text { Stocky Sand Snake }\end{array}$ \\
\hline 15 & Natricidae & $\begin{array}{l}\text { Amphiesma stolatum } \\
\text { (Linnaeus, 1758) }\end{array}$ & $\begin{array}{c}\text { Striped Keelback, } \\
\text { Buff-striped Keelback }\end{array}$ \\
\hline 16 & & $\begin{array}{l}\text { Macropisthodon plumbicolor } \\
\text { (Cantor, 1839) }\end{array}$ & $\begin{array}{l}\text { Green Keelback, } \\
\text { Lead Keelback }\end{array}$ \\
\hline 17 & Pythonidae & Python molurus (Linnaeus, 1758) & Indian Rock Python \\
\hline 18 & Sibynophiidae & $\begin{array}{c}\text { Sibynophis subpunctatus } \\
\text { (Dumeril, Bibron and Dumeril, 1854) }\end{array}$ & $\begin{array}{l}\text { Dumerils Black-headed Snake, Jerdon's Many-toothed } \\
\text { Snake }\end{array}$ \\
\hline 19 & Typhlopidae & Indotyphlops braminus (Daudin, 1803) & Brahminy Worm Snake \\
\hline
\end{tabular}




\begin{tabular}{|c|c|c|c|}
\hline & \multicolumn{3}{|c|}{ Venomous Snakes (V) } \\
\hline 20 & Elapidae & Bungarus caeruleus (Schneider, 1801) & Common Indian Krait \\
\hline 21 & & Naja naja (Linnaeus, 1758) & $\begin{array}{c}\text { Spectacled Cobra, } \\
\text { Common Indian Cobra }\end{array}$ \\
\hline 22 & & Calliophis melanurus (Shaw, 1802) & Slender Coral Snake \\
\hline 23 & Viperidae & Daboia russelii (Shaw and Nodder, 1797) & Russell's Viper, Chain Viper \\
\hline 24 & & Echis carinatus (Schneider, 1801) & Indian Saw-scaled Viper \\
\hline 25 & & Trimeresurus gramineus (Shaw, 1802) & $\begin{array}{c}\text { Indian Bamboo Pit Viper, } \\
\text { Green Pit Viper }\end{array}$ \\
\hline
\end{tabular}

Table 2: List of families with number of genera and species of snakes recorded from Panvel

\begin{tabular}{|c|c|c|c|c|}
\hline Sr. No. & Order & Family & Genera & Species \\
\hline 1 & Squamata & Colubridae & 09 & 10 \\
\hline 2 & Squamata & Elapidae & 03 & 03 \\
\hline 3 & Squamata & Erycidae & 01 & 02 \\
\hline 4 & Squamata & Homalopsidae & 01 & 01 \\
\hline 5 & Squamata & Lamprophiidae & 01 & 01 \\
\hline 6 & Squamata & Natricidae & 02 & 02 \\
\hline 7 & Squamata & Pythonidae & 01 & 01 \\
\hline 8 & Squamata & Sibynophiidae & 01 & 01 \\
\hline 9 & Squamata & Typhlopidae & 01 & 01 \\
\hline 10 & Squamata & Viperidae & 03 & 03 \\
\hline Total & 01 & 10 & 23 & 25 \\
\hline
\end{tabular}


considering its impact on biodiversity. As a result, the herpatofauna from the study area is facing stress and are victimized to accidental road kills (Pawar et al., 2019 a, b).

Present study reveals the mortality of Russell's Viper, Common Wolf Snake, Banded Kukari, Rat Snake and Indian Rock Python is of serious concern noted in this study (Fig. 4). High rate of mortality recorded for snakes is attributed to the attraction of the snakes on the roads for thermoregulation and warmth during early morning when the air temperature is cool. It is also correlated to the sluggish nature of pythons and sand boas to make them more susceptible to mortality (Baskaran and Boominathan, 2010).

Mortality of snakes noted in this study is also correlated to the loss of habitat due to deforestation, overexploitation of natural resources for ongoing construction of NaviMumbai International Airport (NMIA), habitat fragmentation due to construction and widening of roads and rampant urbanization and industrialization of the area adjoining Panvel (Bonaudo et al., 2005). Results of the study are in agreement with the findings regarding anthropogenic impact on snake diversity by Pradhan et al. (2014), Janani et al. (2016), Joshi et al. (2017), Lalremsanga et al. (2018) and Kale et al. (2019).

At present, ecological conditions in area adjoining Panvel, Navi Mumbai supports moderate density of snakes but due to over-exploitation of natural resources for ongoing construction of Navi Mumbai International Airport, deforestation, intense industrialization and urbanization, coastal pollution will affect the diversity and distribution of snakes in future. Therefore, data presented in this paper can be taken as a base line data for future study.

\section{Conclusion}

The study shows that, at present, ecological conditions in area adjoining Panvel, Navi Mumbai supports moderate snake density. It can be concluded that over-exploitation of natural resources and deforestation in Panvel region due to ongoing construction of Navi Mumbai International Airport (NMIA) are the key factors affecting the diversity and distribution of snake species. Also, mortality of snakes in residential complexes is due to lack of awareness regarding ecological role of snakes and fear of snake bite. It is recommended to create awareness among general public about role of snakes in ecological food chain and also sustainable utilization of natural resources. Since no earlier reports are available, data presented here can be taken as a baseline data in knowing the status of snakes from adjoining area of Panvel, Navi Mumbai and effect of industrial development on it.

\section{Acknowledgement}

Encouragement and support provided by Dr. Ganesh A. Thakur, Principal, Mahatma Phule Arts, Science and Commerce College, Panvel, Raigad, Navi Mumbai, India is gratefully acknowledged. Authors are thankful to The Head, Department of Zoology for providing necessary facilities for the present study. Special thanks to Mr. Dhiraj Tamhane, Mr. Samir Mhatre, Mr. Anshuman Kadam and Miss Sailee Dabhane for providing photographs of snakes.

\section{References}

Altaf M, Arshad J, Abdul MK, Khan MSH, Muhammad U and Zulfiqar A. (2018) Anthropogenic impact on the distribution of the birds in the tropical thorn forest, 
Punjab, Pakistan. J. Asia-Pacific Biodiver. 11: 229236. https://doi.org/10.1016/j.japb.2018.03.001.

Baishya B and Das AN. (2018) A preliminary survey on diversity and distribution of snake fauna in Nalbari District of Assam, North Eastern India. Asian Resonance 7: 25-31.

Bansode SA and More VR. (2018) An updated list of serpent from Palghar district of Maharashtra, India. J. Entomol. Zoology Studies 6: 375-379.

Bansode SA, More VR and Mirza KA. (2016) A Study on snakes from Mokhada and Jawhar (Dist. Palghar) Maharashtra, India. Intern. J. Fauna Biol. Studies 3: 103-115.

Baskaran N and Boominathan D. (2010) Road kill of animals by highway traffic in the tropical forests of Mudumalai Tiger Reserve, southern India. J. Threatened Taxa 2: 753-759.

Bawaskar Prakas S and Bawaskar Kiran S. (2016) Herpetofauna diversity from Khamgaon, district Buldhana (M.S.) Central India. Int. J. Life Sci. 4: 412-418.

Bohm M, Kemp R, Williams R, Ana DD, Andrés G, Kirsten MMcMillan, Huw RB and Ben C. (2017) Rapoport's rule and determinants of species range size in snakes. Diversity Distributions 23:1472-1481. https://doi.org/10.1111/ddi.12632

Bonaudo T, Yvonnick LP, Jean FF and Darcisio Q. (2005) The effects of deforestation on wildlife along the transamaz on highway. Eur J Wildl Res. 51: 199-206.

Daniel JC. (2002) The book of Indian reptiles and amphibians. Bombay Natural History Society, Oxford University Press. pp. 238. (ISBN 019566099-4).

Fellows S. (2014) Species diversity of snakes in Pachmarhi Biosphere Reserve. Entomol Ornithol Herpetol. 4: 136. doi:10.4172/2161-0983.1000136.

Ganesh SR, Chadramouli SR, Sreekar R and Gowri SP. (2013) Reptiles of the Central Western Ghats, India A reappraisal and revised checklist, with emphasis on the Agumbe Plateau. Russian J. Herpetol. 20: 181-189.

Gibbons JW, David ES, Travis JR, Kurt AB, Tracey DT, Brian SM, Judith LG, Tony M, Yale L, Sean P, Christopher TW. (2000) The global decline of reptiles, Déjà Vu Amphibians: Reptile species are declining on a global scale. Six significant threats to reptile populations are habitat loss and degradation, introduced invasive species, environmental pollution, disease, unsustainable use, and global climate change. BioScience 50: 653-666, https://doi.org/10.1641/0006-3568(2000)050[065 3:TGDORD]2.0.CO;2
Jadhav PL, Shivaji PC and Harshad ST. (2018) Snake species diversity and their distribution in and around Nanded city, Maharashtra, India. J. Entomol. Zoology Studies 6: 1855-1860.

Janani S, Maheshwaran EG, Leenu J, Samuel T and Raveen R. (2016) Diversity of snakes rescued at Chennai, Tamil Nadu, India. Intern.l J. Fauna Biol. Studies 3: 81-86.

Joshi PS, Charjan AP and Tantarpale VT. (2017) A herpetofaunal inventory of Vidarbha region, Maharashtra, India. Bioscience Discovery 8: 582-587.

Kale GB, Vairale S and Ghait SN. (2019) Study of snake species diversity in rural and semi urban areas of Buldhana district of Maharashtra, India. Intern. J. Life Sci. A13: 219-225.

Koirala BK, Gurung DB, Lhendup P and Phuntsho S. (2016) Species diversity and spatial distribution of snakes in Jigme Dorji National Park and adjoining areas, western Bhutan. J. Threat. Taxa 8: 9461- 9466.

Lalremsanga HT, Saipari S and Chinliansiama. (2018) Diversity of Snakes (Reptilia: Squamata) and role of environmental factors in their distribution in Mizoram, Northeast India. Adv. Environ. Chem. 79: 265-268.

Luiselli L, Leonardo S, Godfrey CA and Giovanni A. (2020) Venomous snake abundance within snake species' assemblages worldwide. Diversity. 12, 69. doi:10.3390/d12020069.

Manhas A, Rajni R and Ashwani W. (2016) An assessment of reptilian diversity and their distribution in Jammu and Kashmir state from Jammu city in northern India: A case study. Intern. J. Fauna Biol. Studies 3: 20-23.

Masood MF. (2012) Ecological studies on the diversity of terrestrial poisonous snakes "Proteroglyphous" of Jazan region Kingdom of Saudi Arabia (Reptilia: Ophidia). Egyptian J. Hospital Med.. 49: 839- 856.

Mukadam M and Gautam K. (2016) A preliminary survey on the snakes of Ratnagiri and Sindhudurga districts of Konkan region of Maharashtra. Intern. J. Adv. Res. Sci. Engineering Technol. 3: 3072-3077.

Pauwels OSG, Van W and Patrick D. (2008) Global diversity of snakes (Serpentes; Reptilia) in freshwater. Hydrobiologia 595: 599-605.

Pawar Prabhakar R. (2013) Monitoring of impact of anthropogenic inputs on water quality of mangrove ecosystem of Uran, Navi Mumbai, west coast of India. Mar. Poll. Bull. 75: 291-300.

Pawar Prabhakar R, Atul JP, Anil GR, Namdeo BP and Shreya RP. (2019b) Monitoring of anthropogenic 
threats to mangrove ecosystem of Panvel Creek, Navi Mumbai, India. Research Chronicler 7: 74-84.

Pawar Prabhakar R, Meshram LN, Udawant SM and Inamdar RF. (2019a) Assessment of coastal pollution using faunal composition of macrobenthos from Panvel Creek, Navi Mumbai, West Coast of India. Research Chronicler. 7: 28-38.

Petty MR. (2019) A primer on reptiles and amphibians. Louisiana Exotic Animal Resource Network, Elm Grove, LA 71051, USA. Version 1.0. pp. 176. ISBN: 978-0-692-15712-1.

Pradhan S, Devraj M and Sahu KR. (2014) An inventory and assessment of snake diversity of Gandhamardan hills range of western Orissa, India. Int. J. Pure Appl. Zool. 2: 241-245.

Raut SR, Shantaj MD, Jyotsna AM, Vijay KH, Singh AJ and Mehta Gayatri U. (2014) Recent studies on the biodiversity of snakes in Palghar region, Thane, Maharashtra, India. Adv. Appl. Sci. Res.. 5: 373-381.

Rodrigues ASL, Gray CL, Crowter BJ, Ewers RM, Stuart SN, Whitten T and Manica A. (2010) A global assessment of amphibian taxonomic effort and expertise. Bioscience 60: 798-806.

Sirsat CV, Patil M and Ujiwal V. (2016) Analysis of data on snakes diversity and ecological status from Aurangabad district, (MS) India. Bioscience Discovery 7:162-165.
Sulabh S and Shivahre PR. (2018) Common poisonous snakes of india - A review. World J. Pharmaceu. Res. 7: 431-442.

Tambre GN and Chavan SP. (2016) Snake species diversity of Swami Ramanand Teerth Marathwada University, Nanded, Maharashtra State, India. Int. J. Curr. Res. Aca. Rev. 4: 104-115.

Uetz P. (2010) The original descriptions of reptiles. Zootaxa 2334: 59 - 68. (ISSN 1175-5334).

Vignoli L, Andrea C, Giuseppe L, Luca L and Daniele S. (2017) The distribution and diversity of reptiles in a species-rich protected area of Central Italy. Herpetol. Conser. Biol. 12: 279-291.

Walmiki N, Siddhesh K, Bhaskar Y, Manisha K, Vishal W, Rishab P and Swapnil D. (2012) Herpetofauna of Bassein Fort and surrounding region, Thane, Maharashtra, India. Trends Life Sci. 1: 1-11.

Whitaker R. (2006) Common Indian snakes: A field guide. Macmillan India Limited, Delhi. pp. 138. (ISBN: 1403929556, 9781403929556).

Yadav OV, Yankanchi SR and Amol MP. (2014) Diversity, threats and conservation of herpetofauna in Shivaji University Campus, Kolhapur, Maharashtra, India. Int. J. Curr. Microbiol. App. Sci. 3: 742-749. 